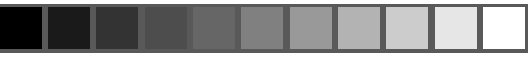

\title{
MODSTANDSDYGTIGHED OVER FOR STATSSTYRET IKONOKLASME BLANDT LOMA I GUINEA
}

Denne artikel er det danske resumé af afhandlingen Resisting State Iconoclasm among the Loma of Guinea. Den 6. februar 2006 blev afhandlingen antaget til forsvar for den antropologiske doktorgrad af det Samfundsvidenskabelige Fakultet, Københavns Universitet, og den er udgivet i Carolina Academic Press' Ritual Studies Monograph Series.

Resisting State Iconoclasm among the Loma of Guinea er et antropologisk studie af de årsagssammenhænge, der ligger til grund for en vestafrikansk lokalbefolknings vedvarende udøvelse af deres såkaldt traditionelle religion. Emnet vedrører en religiøs praksis, der fra at have været genstand for statsstyret voldelig undertrykkelse siden hen har udviklet sig til et instrument for vold begået mod nabofolk. Studiet af den tilsyneladende kontinuitet af religiøse forestillinger og rituelle handlinger baserer sig på to og et halvt års etnografisk feltarbejde udført i flere omgange blandt mande-talende lomafolk i det sydøstlige Guinea i perioden 1990-1999. Undersøgelsen inddrager desuden historisk og komparativt, regionalt materiale af både ældre og nyere dato fra det øvre Guineas skov- og kystområde, som foruden Guinea bl.a. omfatter landene Liberia og Sierra Leone.

Afhandlingens tese er, at forskellige former for lokal, refleksiv viden har haft afgørende indflydelse på den varige, succesfulde udbredelse af de religiøse ideer og handlinger, der knytter sig til den lokale kategori sale. Den anvendte teoretiske model til forklaring af religiøs kontinuitet bygger dels på nyere teorier om kognition med fokus på de kognitive og psykologiske processer i overførslen og repræsentationen af kulturel viden og dels på den klassiske socialantropologis begreb om religiøse forestillingers og rituelle handlingers indlejring i sociale relationer. Afhandlingen argumenterer for, at kognitiv teori og antropologi om sociale relationer isoleret set er utilstrækkelige analytiske tilgange i forhold til en fyldestgørende løsning af den stillede opgave. Hvor kognitiv teori tenderer mod at være „samfunds- og kulturblind“, i den udstrækning den nedtoner betydningen af sociokulturel kontekst, er standardsocialantropologi kendetegnet ved at være „bevidsthedsblind“, i den forstand at den hviler på en utilstrækkelig teori om de psykologisk-kognitive processer, der er involveret i tilegnelsen, overførslen og repræsentationen af kulturel viden blandt individer og sociale grupper. I forening yder de to perspektiver imidlertid et plausibelt 

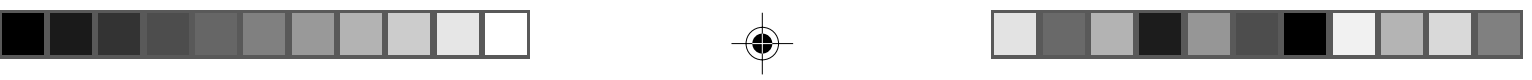

svar på forudsætningerne for forekomsten af et kontinuerligt, komplekst kulturelt fænomen. Med det særlige fokus på forskellige grader af individuel og kollektiv religiøs bevidsthed samt på sociale og politiske faktorers påvirkning af en lokal religiøs tradition kan den udviklede model til forklaring af religiøs kontinuitet blandt lomafolket ses som et kritisk bidrag til den ,repræsentationsepidemiologi“, der har vundet udbredelse inden for dele af den nyere antropologiske og religionsvidenskabelige kognitionsforskning. Afhandlingen er på 350 sider. Den indeholder 11 kapitler samt noter, landekort, illustrationer og en litteraturliste.

\section{Baggrund}

Lomafolket, der lever i grænseregionen mellem Guinea og Liberia, udgør trods deres relativt store antal (ca. 250.000) en etnisk minoritet blandt mande-talende folk i et større område af Vestafrika. De hører til blandt gruppen af såkaldt „,perifere mande“, der gennem et par eller flere århundreder har befundet sig i en mere eller mindre permanent konflikt med de demografisk, politisk og økonomisk dominerende mandingofolk. Hovedparten af loma er landbefolkning og lever overvejende af risdyrkning samt en række handelsafgrøder (fx kaffe, jordnødder og spiseolie) suppleret med jagt og fiskeri i de talrige floder, der gennemløber dette område af Vestafrika. Et stigende antal loma har i de seneste årtier bosat sig i regionale, multietniske byer eller i store landsbyer langs hovedfærdselsårerne, hvor de dels lever af landbrug og dels af andre håndværkserhverv samt detailhandel og kontraktarbejde. Kristendom blev introduceret blandt loma af franske, katolske og amerikanske, protestantiske missionærer umiddelbart efter koloniseringen i begyndelsen af det 20. århundrede. Der har dog været tale om en minimal gennemslagskraft for denne nye religions vedkommende op gennem århundredet. Kun få loma og typisk de, der er bosat i urbane områder, er konverteret til kristendom og det ofte uden at opgive lokal religiøs praksis. I de to seneste årtier præget af omfattende politiske og voldelige konflikter har man kunnet spore en øget tilstedeværelse af adventistkirker, der i disse år vinder stor udbredelse blandt flere af verdens kriseramte og fattige befolkninger, især i Afrika og Sydamerika. Islam, som nyder stor udbredelse i Guinea og Vestafrika i øvrigt, har på den anden side stort set ingen tilhængere blandt loma. Den udeblivende tilslutning til islam skyldes tilsyneladende, at denne religion associeres direkte med de dominerede mandingonabofolk, som loma længe har stået i et konfliktfyldt forhold til.

Baggrunden for at vælge at undersøge lomafolkets fastholdelse af sin lokale religion skyldes ikke først og fremmest, at man ikke som så mange andre steder i Afrika har taget de store verdensreligioner islam og kristendom til sig. Det foreliggende studie af lomareligion og politisk kultur ved overgangen til det 21 . århundrede tager derimod afsæt $\mathrm{i}$ en bestemt historisk begivenhed, der knytter sig til tiden omkring Guineas opnåelse af uafhængighed fra den tidligere franske kolonimagti 1958. Som led i frigørelsen fra fremmed overherredømme og udviklingen af en moderne nationalstat iværksatte den første postkoloniale regering $\mathrm{i}$ Guinea under den karismatiske præsident Sekou Tourés ledelse en officiel ,afmystificeringskampagne“. „Afmystificeringskampagnen“ forløb officielt og mest intensivt i perioden 1959-1961, men fortsatte i realiteten i de følgende to årtier. Det var en kombination af socialisme og vilje til modernisering, der udgjorde rationalet bag kampagnen og som rettede sig mod religion i almindelighed. Ud over den signalværdi, en sådan kampagne 

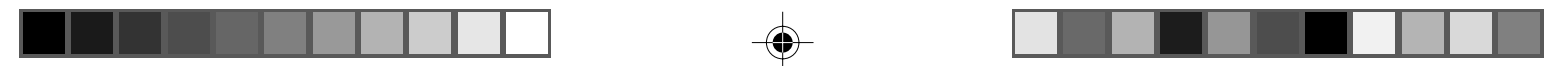

måtte have i forhold til omverdenen, var hensigten gennem tvang at udrydde de lokale, såkaldt traditionelle former for religiøs praksis, der ikke alene repræsenterede irrationel „overtro“, men som man tillige antog kunne stimulere etnisk samhørighedsfølelse. Det var således netop lokale former for identitetsdannelse, som den guineanske politiske elite på det tidspunkt opfattede som en hindring for opbygningen af en moderne nationalstat, hvis bestemmelse var og muligvis fortsat er at forene en heterogen befolkning på tværs af historiske, regionale og partikulære etniske skel. Den politisk styrede ,afmystificeringskampagne" tog form af ikonoklasme for så vidt, at den indebar destruktion af religiøse symboler og forbud mod udøvelsen af rituelle handlinger. Desuden blev den ledsaget af ideologisk opbyggelige teaterforestillinger blandt lokalbefolkninger, og magthaverne benyttede sig også af nye kommunikationsveje som fx radio på lokalsprog i bestræbelsen på at løfte det, man opfattede som et slør af tilbagestående, irrationel mentalitet med hæmmende virkning i forhold til moderniseringen af den nyetablerede nationalstat. Kampagnen blev i realiteten først afblæst i starten af 1990'erne, da Guinea i lighed med andre afrikanske lande under pres fra det internationale samfund indledte en liberalisering af økonomien og demokratisering af de politiske forhold.

Loma viste sig at være en særlig udsat målgruppe for ,afmystificeringskampagnen“, sandsynligvis på grund af den lokale religions prototypiske karakter i form af hemmelige indvielsesselskaber for mænd og kvinder, mangfoldige maskekulter og tilstedeværelsen af en lang række symboler, der blev betegnet nedsættende som ,feticher“. På trods af den massive undertrykkelse af lomafolkets religiøse praksis gennem cirka tre årtier, herunder afsløring af hemmeligholdte ritualer og religiøse symboler, er hovedparten af denne befolkning fortsat, først $\mathrm{i}$ al hemmelighed og siden mere åbenlyst, med at besværge de samme guder og udføre de samme ritualer, som man gjorde, da de første kristne missionærer ankom til området i 1920'erne, og før det statsligt styrede omvendelsesforsøg blev sat i værk i 1959. Det er afhandlingens ambition at opklare spørgsmålet om den lokale religions øjensynlige uberørthed af et så gennemgribende forsøg på udryddelse i form af forbud, fysisk destruktion af kultgenstande, ydmygelse af rituelle specialister og afsløring af religiøse hemmeligheder.

Spørgsmålet om den religiøse ikonoklasmes ineffektivitet knytter sig til et mere generelt spørgsmål om en lokal religiøs praksis' kontinuitet anskuet ved overgangen til det 21 . århundrede. Afhandlingens centrale analytiske spørgsmål vedrører således årsagen, eller måske rettere årsagerne, til den varige, succesfulde udbredelse af lomafolkets lokale religion. Ikke alene er lomas forhold til egen religion forblevet tilsyneladende uberørt af langvarig undertrykkelse. Den lokale religion har endvidere vist sig at spille en aktiv rolle i det politiske liv i det sydøstlige Guinea og nordvestlige Liberia i løbet af 1990'erne. Man kan for så vidt tale om en revitalisering af lokal religion i forbindelse med forandringer i den nationale politiske kultur og heraf delvis afledte lokale konflikter af etnisk og økonomisk art. Borgerkrigen i nabolandet Liberia har ligeledes medvirket til at styrke den lokale religions betydning.

Afhandlingen hviler på en analytisk deling af det ledende spørgsmål om kontinuiteten af lokal religion. Det drejer sig på den ene side om at forklare den tilsyneladende uberørthed over for den guineanske stats overgreb. På den anden side forekommer det vigtigt at redegøre for den lokale religiøse praksis' involvering i det politiske liv i nyere tid. Hvor sidstnævnte proces er udtryk for kontinuiteten i den ene eller anden form af lomareligion, er immuniteten over for destruktive overgreb en forudsætning for, at den eksisterende 

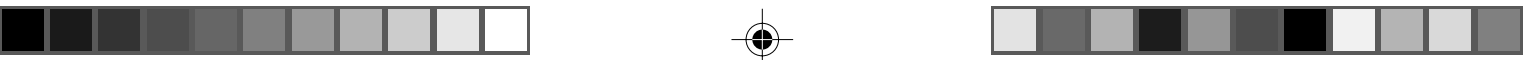

religiøse praksis har kunnet videreføres. Mekanismerne bag religionens modstandsdygtighed og fortsatte sociokulturelle og politiske relevans er ikke nødvendigvis de samme, og de behandles derfor i to omgange, men de bidrager i fællesskab til en og samme proces, nemlig sikringen af den lokale religions succesfulde udbredelse over tid.

\section{Afhandlingens tese}

Det er afhandlingens tese, at det vestafrikanske lomafolks fastholdelse af traditionel rituel handling og symbolisme kan forklares med henvisning til former for refleksiv viden, der dels udgør en indre egenskab ved rituel ceremoniel og organisation, og dels resulterer $\mathrm{i}$ begivenheder af ekstern politisk art. Afhandlingens tese indeholder således to aspekter. Refleksivitet anskues for det første som en indre egenskab ved rituel praksis hos loma, der bidrager til at foregribe og immunisere udenforstående aktørers bestræbelse på at destruere den rituelle praksis gennem ødelæggelse, forbud og afsløring af rituel hemmelighed. Tesens andet aspekt vedrører den refleksivt konstituerede viden om rituel praksis, der følger af eksterne påvirkninger af lomasamfundet især i løbet af 1990'erne i form af begyndende demokratisering af de politiske forhold, etnisk konflikt og identitetspolitik samt borgerkrig. Som en attitude til viden bliver begrebet refleksivitet i denne sammenhæng anvendt til at betegne forskellige former for bevidsthed, der opstår, når en særlig viden eller en bestemt handling vender sig mod sig selv og bliver sit eget objekt.

Der er flere faktorer, der betinger lomamænd og -kvinders refleksive bevidsthed om deres religiøse viden og rituelle praksis. Religiøs refleksivitet er for det første knyttet til den rituelle handlings organisering, herunder forekomsten af rituelt sprog og betingelserne for overførsel af religiøse ideer. Til illustration af dette aspekt fokuserer afhandlingens første del på kultmedlemmers erfaring af fremtrædende ulykkesvangre begivenheder, begrebslig refleksivitet, som den udvikles under ofringsritualer, samt den type af refleksiv viden, der er givet med hemmeligholdelse som et led i rituel performance og som et middel til at kontrollere kommunikationen af viden. Religiøs refleksivitet er for det andet et produkt af den objektivering af religiøse forestillinger, der følger af mødet med udenforstående aktører og deres måder at forholde sig til lomas religiøse praksis på. De eksterne aktører omfatter både en uddannet urban lomaelite med regionale og nationale politiske ambitioner og de mandingonabofolk, som loma (næsten) altid har befundet sig i et konfliktpræget forhold til.

Kapitlerne 3-5 i afhandlingen redegør for de former for refleksivitet, der er indeholdt i selve den rituelle praksis. Kapitlerne 7-9 redegør omvendt for den styrkelse og mulige forandring af rituel praksis, der er opstået med politiseringen af lomareligion ved overgangen til det 21. århundrede. I sidstnævnte tilfælde bliver den lokale bevidsthed om rituel praksis og rituelle institutioner til og går hånd i hånd med en midlertidig transformation af lokal religion til et medium for modstand og vold i lomafolkets interaktion med den umiddelbart omgivende verden.

Til forklaring af kontinuiteten af lomareligion antager afhandlingen, at de endogene faktorer, der er bestemmende for kultdeltageres immunitet over for den statsstyrede ikonoklasme og deres vedvarende religiøse engagement, danner grundlaget for den revitaliserende effekt af eksogene faktorer i forhold til religiøs tradition hos loma. Forudsætningen for, at sociopolitiske faktorer kan påvirke en religion og herunder at udenforstående kan 

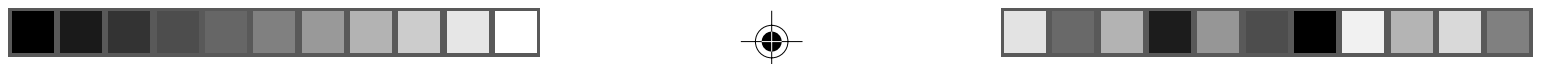

manipulere succesfuldt med religiøs symbolik, er, at disse påvirkninger i et vist omfang har klangbund i befolkningens erfaring med allerede eksisterende rituel praksis og mentalt indhold. Som en følge heraf går beskrivelsen og analysen af de kognitive og relationelle processer, der er involveret $\mathrm{i}$ tilegnelsen, overførslen og repræsentationen af religiøse ideer og rituel praksis, forud for studiet af påvirkningen af omsiggribende politiske begivenheder på den lokale religion.

\section{Kapitelpræsentation}

Introduktionskapitlet præsenterer den allerede skitserede problemstilling vedrørende kontinuiteten af religiøs praksis hos loma og den metodiske og teoretiske ramme for afhandlingen. Kapitlet giver en første, kort redegørelse for det religiøse kompleks, som er undersøgelsens primære empiriske genstand. Det drejer sig om en lokal kategori sale, der umiddelbart kan oversættes med det familiære begreb medicin, men som ved nærmere eftersyn viser sig at være en mere kompleks semantisk kategori. Sale henviser således til en særlig type af åndelige væsener, en form for skytsånder, men kategorien anvendes ligeledes til at betegne medicinske produkter, traditionelle såvel som moderne, samt materielle manifestationer af saleånder i form af masker, feticher og spådomsmedier. Loma anvender desuden salekategorien til at beskrive de kultgrupper, der på et lokalt plan forener personer, der er knyttet til den samme type saleånd, samt de rituelle aktiviteter, som udføres i kultregi.

Indledningskapitlet er først og fremmest begrebsafklarende. Det præsenterer afhandlingens metodiske og teoretiske position. Til en begyndelse indeholder kapitlet en kritisk diskussion af nyere antropologiske studier af tilsyneladende kulturel og religiøs kontinuitet inden for de retninger, man kan betegne som henholdsvis ,,invention-of-tradition“-skolen og det modernitetsdialektiske paradigme. Fælles for begge, delvis beslægtede retninger er, at de opfatter lange kulturhistoriske træk som et produkt af aktuelle forhold. Således anskuet giver det ingen mening at forklare sociokulturel robusthed med henvisning til historisk dybde eller evolutionært udviklede psykologisk-kognitive dispositioner hos mennesket som individ og socialt væsen. Som årsag til tilsyneladende reproduktion af tidligere kulturelle ideer og institutioner henviser man i stedet typisk til politiske eliters manipulation med kulturelle symboler eller til den prekære, fejlslagne modernitet, som man i perifere egne af verden re-agerer på ved at genopdage (læs: konstruere) bestemte kulturelle traditioner. Resultatet er, at fænomener af tilsyneladende historisk karakter først og fremmest beskrives som noget grundlæggende nyt. Uden at afvise relevansen af dette perspektiv for forståelsen af de politiske implikationer af flamboyante hekseriepidemier og lignende i visse områder af det aktuelle Afrika argumenterer afhandlingen for nødvendigheden af at tage spørgsmålet om kontinuitet alvorligt som kontinuitet, dvs. i betydningen af lomafolkets vedvarende engagement med deres lokale religiøse praksis. Med fokus på individers og sociale fællesskabers evne til at genkalde sig mere eller mindre hyppigt udførte ritualer og på motivationen til at videreføre dem lægger afhandlingen op til en anden form for teoretisk behandling af det studerede eksempel end den neofunktionalisme, der præger mange aktuelle studier af reproduktionen af lokal religion i lyset af moderne politisk liv og psykiske behov. Den politiske situation er, som allerede nævnt, relevant for forståelsen af kontinuiteten af religiøs praksis hos loma, men afhandlingen argumenterer for betydningen af at forstå 

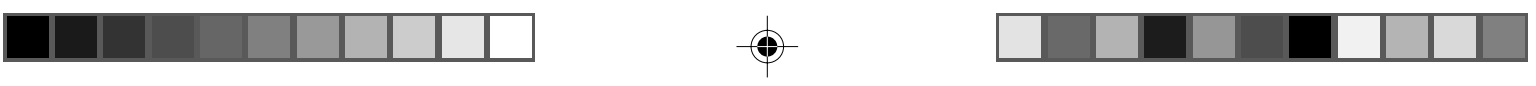

det religiøse kompleks uafhængigt af den overordnede politisk orden, i det omfang det er muligt, før artikulationen af det politiske og det religiøse gøres til genstand for tematisering.

Indledningskapitlet forholder sig ligeledes til spørgsmålet om studiet af religiøs symbolisme generelt samt en række beslægtede regionale studier af religiøs symbolisme, især blandt kpellefolket i Liberia og mendefolket i Sierra Leone. Til forskel fra de eksisterende betydningscentrerede, strukturalistiske og funktionalistiske studier af kollektive religiøse forestillinger og rituelle handlinger i den omgivende region fokuserer den foreliggende afhandling på ritualdeltagernes kognitive organisering af religiøse ideer og på distributionen af rituel viden blandt medlemmer og ikke-medlemmer af lokale salekulter. Det analytiske objekt og teoretiske perspektiv bliver yderligere præciseret gennem en diskussion af, hvad der ligger i at studere (religiøs) traditionsoverførsel. Der optræder desuden en kort forskningshistorisk redegørelse for antropologiske studier af religiøs rituel kontinuitet. Kapitlet afsluttes med nogle betragtninger over de etiske betingelser, som knytter sig til en antropologisk feltarbejdsbaseret undersøgelse af en religiøs praksis, der er kendetegnet ved en udpræget grad af diskretion og hemmeligholdelse.

Kapitel 1 „The one and the many: Guinean policies of iconoclasm“ redegør for baggrunden for og dokumentationen af de postkoloniale guineanske myndigheders forsøg på at udrydde såkaldt traditionel, polyteistisk religion. Kapitlet belyser således den overordnede ramme for spørgsmålet om en lokal religions levedygtighed. På den ene side beskrives den vanskelige fase $\mathrm{i}$ den tidligste postkoloniale periode, hvor alle politiske kræfter i Guinea blev investeret i opbygningen, ideologisk såvel som institutionelt, af en fælles nationalstat. Denne udviklingsproces blev i datiden opfattet som selve retfærdiggørelsen af den statsstyrede ikonoklasme. På den anden side præsenterer kapitlet både første- og andenhåndsbeskrivelser af ikonoklasmehandlinger blandt loma.

Kapitel 2 „The Loma“ udgør en monografi i monografien. Det giver en generel indføring i lomakultur og samfund aktuelt og historisk. Hensigten med dette kapitel er først og fremmest at illustrere, i hvilket omfang lomasamfundet eller rettere spredte, autonome lomasamfund kan siges at have haft del i en turbulent, foranderlig historie. I modsætning til hvad der er almindelig opfattelse i Guinea og Liberia, har loma tydeligvis aldrig været isoleret fra omgivende samfund, herunder dominerende udefrakommende økonomiske, politiske, militære og religiøse kræfter. Kapitlet dokumenterer, at den lokale religiøse praksis' robusthed ikke kan ses som en effekt af tilsyneladende regional isolation i det guineanske og liberianske bagland.

Kapitel 3 „The art of Loma masking“ er bogens første detaljerede indføring i de forestillinger, symboler, ritualer og hemmelige kulter, der omfattes af kategorien sale. Maskekulter er valgt som et prototypisk eksempel på de mangeartede salekulter. Kapitlet giver ligeledes en detaljeret beskrivelse af lomamaskerade. Det fremgår af analysen af de relationelle aspekter ved maskerade, at denne form for rituel handling spiller en væsentlig rolle i formningen af forholdet mellem essentielle sociale kategorier som fx indviede og ontologiske status af kognitive skemaer for religiøse forestillinger og det hermed forbundne problem vedrørende årsagsslutninger inden for rammerne af det, man kunne kalde ,troen“ på sale. Derudover indeholder kapitlet en beskrivelse af indvielsen i salekulter, kulternes organisation og principperne for kommende rituelle eksperters indføring i rituel og medicinsk saleviden.

Kapitel 4 „Belief-fixation: The transmission and acquisition of religious knowledge” analyserer forholdet mellem individuelle og kollektive forestillinger om saleånder, som de 

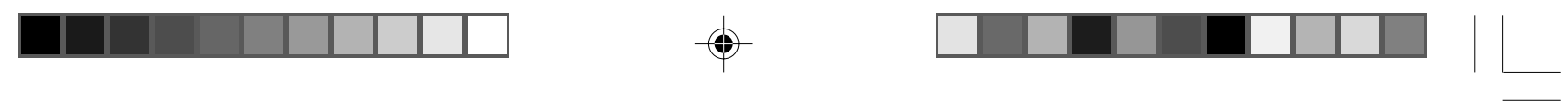

kommer til udtryk i salekultmedlemmers genkommende fortællinger om „mødet” med deres personlige skytsånd. I kapitlet indgår også en diskussion af spørgsmålet om den ontologiske status af kognitive skemaer for religiøse forestillinger og det hermed forbundne problem vedrørende årsagsslutninger inden for rammerne af det, man kunne kalde ,troen“ på sale. Derudover indeholder kapitlet en beskrivelse af indvielsen i salekulter, kulternes organisation og principperne for kommende rituelle eksperters indføring i rituel og medicinsk saleviden.

Kapitel 5 „Ritual speech in sale sacrifice“ flytter fokus fra fortællinger og andre eksterne beskrivelser af salerelaterede aktiviteter og kulter til et detailstudie af den direkte verbale kommunikation med saleånder samt kommunikationen med disse gennem offerhandling. Det fremgår af analysen af den rituelle bøn, at lokale forestillinger om sale indeholder mere end blot henvisninger til mystiske, såkaldt overnaturlige kræfter. Den systematiske adressering af distinkte typer af forfædre illustrerer, at rituel symbolik forbundet med sale i vid udstrækning hviler på en rekonfiguration i den rituelle bøn af to typer sociale relationer, som er karakteristiske for social struktur hos loma. Det drejer sig henholdsvis om forholdet til slægtninge i moderens eller faderens vertikalt organiserede afstamningslinje og om forholdet til rituelle specialister i de horisontalt organiserede salekulter, som de fleste loma er medlem af. Bønnen til saleånderne spejler ikke som sådan den eksisterende sociale orden, endsige ideelle forestillinger herom. Den rituelle bøn konstruerer derimod en selvreferentiel kontekst, man kan vælge at se som konstituerende for salekulternes organisationsform.

Kapitel 6 „Inner iconoclasm“ udgør afhandlingens omdrejningspunkt. I lyset af analysen i kapitlerne 3-5 giver kapitlet på den ene side et svar på spørgsmålet om årsagen til lomareligionens immunitet over for statens forsøg på at udrydde lokal religiøs praksis. Analysen indskriver sig som sådan i den klassiske antropologiske debat om rationalitet og irrationalitet i forståelsen af såkaldt primitiv religiøs tænkning. Som forklaring på den tilsyneladende udeblevne påvirkning fra den statsstyrede ikonoklasme peger analysen på tre former for refleksivitet blandt salemedlemmer hos loma. Der er tale om former for refleksivitet, der relaterer sig til nogle grundlæggende processer i overførelsen af kulturelle forestillinger. De identificerede processer vedrører selve tilblivelsen af lokale forestillinger om sale, fastholdelsen af disse forestillinger og endelig kommunikationen heraf. Kapitlet belyser først den selvrefleksivitet, der følger af lagringen i bevidstheden af individuelle oplevelser med saleånder i form af episodisk, åbenbaret viden. Dernæst fremhæver kapitlet den begrebslige refleksivitet, der følger af den figurative fremstilling af en guddom. Herunder indgår der ligeledes en beskrivelse af, hvorledes rituel symbolisme bl.a. tjener til at løse det paradoks, som opstår, når et artefakt transformeres til en levende ting eller omvendt. Den tredje form for refleksivitet i forbindelse med religiøs viden og handling associeret med salekategorien følger af saleviden set som en kommunikativ strategi, der kendetegnes ved brugen af bedrag og hemmeligholdelse. Afslutningsvis lægger kapitlet op til, at spørgsmålet om lomareligionens varige udbredelse kun kan besvares fyldestgørende inden for rammerne af en undersøgelse, der også omfatter de politiske implikationer af lokale religion, historisk og ikke mindst aktuelt.

Kapitel 7 „Loma male initiation“ indeholder en beskrivelse af den mest indflydelsesrige og mest omtalte, men ikke nødvendigvis bedst kendte salekulter hos loma, nemlig det hemmelige mandlige indvielsesselskab, som i den regionale litteratur er kendt under navnet Poro. Kapitlet fremanalyserer de grundlæggende kognitive mekanismer for tilegnelse og 

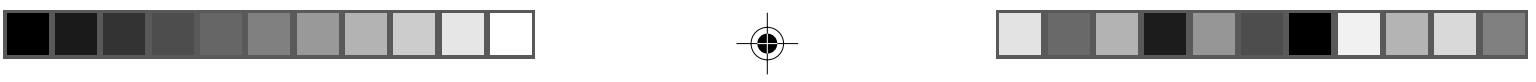

overførsel af religiøs viden, der, indeholdt i et symbolrigt og stærkt følelses-ladet indvielsesritual, bidrager til udviklingen af en social organisationsform med et umiddelbart virkningsfuldt, men samtidig også begrænset potentiale med hensyn til varig-hed og omfanget af medlemmer.

Kapitel 8 „Democratisation, violence and secret society politics“ redegør for intensiveringen af det hemmelige mandsselskab Poros aktiviteter i løbet af 1990'erne. Der argumenteres for, at den ændrede politiske situation på såvel nationalt som internationalt niveau, herunder politisk pluralisme og nationalstatens krise, udgør den egentlige baggrund for udviklingen af en øget etnisk bevidsthed, etnisk konflikt og regional borgerkrig. Til illustration af den lokale religions politiske betydning beskriver kapitlet et eksempel på en maskeceremoni, der udvikler sig til voldeligt overgreb mod lokale mandingofolk med fysiske ødelæggelser og død til følge. Begivenheden analyseres i lyset af den allerede udviklede viden om lomamasketradition (kapitel 3) og perspektiveres yderligere igennem en diskussion af regional litteratur om religiøst motiveret vold. Kapitlet konkluderer, at volden ikke udgør en indbygget adfærd i forbindelse med maskeritualer. At volden er eller kan være repræsenteret $\mathrm{i}$ en latent form i maskerelaterede ritualer synes heller ikke at være årsag til „ritualiserede“" overgreb. Alternativt peges der på, at maskerade som traditionel kulturel performance er begyndt at tage karakter af det omgivende voldelige miljø, maskekulterne er blevet en del af.

Kapitel 9 „Identity politics“ forlænger undersøgelsen af den lokale religions politisering. Loma-Poro har vist sig at spille en afgørende rolle i forandringen af det politiske landskab i nyere tid. Kapitlet diskuterer først og fremmest betydningen af Poro for udviklingen af en fælles etnisk og politisk samhørighedsfølelse blandt lomafolket. Loma har historisk set aldrig udgjort et forenet folk eller en fasttømret etnisk gruppe. Men de har (altid) været fælles om at lade deres unge mænd indvie i det hierarkisk og decentralt organiserede Poroselskab. I de senere år har det vist sig, at Poro kan tjene som et effektivt middel til civilt selvforsvar blandt loma i kampen mod oprørsgrupper fra nabofolket mandingo. Den delvist hemmelige religiøse institution viser sig samtidig at være blevet manipuleret af udenforstående aktører med hensigter, der næppe kan betegnes som religiøse. Lederne af en etnisk selvstændighedsbevægelse ved navn gilibai (,enhed“) har således med relativ succes forsøgt at anvende Poroselskabet som rekrutteringsgrundlag. Det har imidlertid vist sig, at Poroledere kun har ladet sig manipulere i det begrænsede omfang, det har kunnet bidrage til realisering af deres egne hensigter på et lokalt og overvejende religiøst plan. I en afsluttende diskussion af det kognitive grundlag for Poroinstitutionens sociopolitiske dynamik konkluderes det, at den religiøse institution ikke er egnet til sikringen af en varig mobilisering af unge indviede lomamænd på et supralokalt, regionalt plan.

Kapitel 10 „Religious reflexivity: Steps to an epidemiology of Loma religion“ udgør afhandlingens konklusion. Det genrejser spørgsmålet om værdien af at anlægge et kombineret kognitivt og relationelt antropologisk perspektiv på det stillede problem vedrørende årsagen til lomabefolkningens fastholdelse af den lokale religion relateret til kategorien sale. Som vist i de forudgående kapitler rækker hverken den tendentielt „bevidsthedsblinde“ kontekstuelle tilgang eller den tendentielt „,samfunds- og kulturblinde“ kognitive tilgang til at redegøre fyldestgørende for forekomsten af den tilsyneladende kontinuitet af en lokal, såkaldt traditionel religiøs praksis. Kombineret i en og samme analyse forekommer disse to tilgange omvendt at kunne producere et plausibelt svar på det stillede spørgsmål. Kapitlet opsummerer de endogene og eksogene determinanter, der 
antages at forårsage immunitet over for ikonoklasme, motivation for at fastholde og videreføre religiøs rituel viden og praksis, samt fortsat relevans, herunder socialt og politisk, af lokal religiøs praksis.

Under overskriften „Refleksivitetsmåder“ udlægges de interne og eksterne faktorer, der er bestemmende for religiøs robusthed, som distinkte former for lokal objektivering af kulturel viden og kulturel praksis. Der skelnes således mellem en internt genereret refleksivitet, som hovedsagelig opstår gennem rituel handling, og en eksternt genereret refleksivitet, der typisk er resultatet af konfrontationen mellem lokal religion og en omgivende politisk orden. Denne skelnen signalerer samtidig en forskydning i graden af refleksivitet fra et implicit bevidsthedsniveau til en form for eksplicit refleksiv viden om lokal religion. Kapitlet afsluttes med en kritisk diskussion af en bestemt skole inden for kognitiv antropologi, der definerer antropologiens objekt som den varige, succesfulde udbredelse af bestemte kulturelle repræsentationer. I modsætning til repræsentanter for denne retning, der fokuserer på effekten af automatiske og dermed ubevidste psykologisk-kognitive mekanismer, insisterer Resisting State Iconoclasm på relevansen af at inddrage et kulturelt og politisk bevidstheds- og aktivitetsniveau i analysen af den succesfulde videreførelse af kulturelle fænomener som fx lokal religion blandt de vestafrikanske loma.

\section{Litteratur}

Højbjerg, Christian Kordt

2007 Resisting State Iconoclasm among the Loma of Guinea. Durham, NC: Carolina Academic Press. 
